\title{
Management of Obesity in Adults: European Clinical Practice Guidelines
}

\author{
Constantine Tsigos $^{\mathrm{a}} \quad$ Vojtech Hainer $^{\mathrm{b}} \quad$ Arnaud Basdevant $^{\mathrm{c}} \quad$ Nick Finer $^{\mathrm{d}} \quad$ Martin Fried $^{\mathrm{e}}$ \\ Elisabeth Mathus-Vliegen ${ }^{f} \quad$ Dragan Micic $^{g} \quad$ Maximo Maislos $^{h} \quad$ Gabriela Roman $^{i} \quad$ Yves Schutz $^{j}$ \\ Hermann Toplak ${ }^{k}$ Barbara Zahorska-Markiewicz'; for the Obesity Management Task Force of the \\ European Association for the Study of Obesity
}

\author{
a Endocrinology, Metabolism and Diabetes Unit, Evgenidion Hospital, Athens University Medical School, Athens, Greece \\ b Obesity Management Centre, Institute of Endocrinology, Prague, Czech Republic \\ c Department of Endocrinology, Pitié Salpêtrière Hospital; Pierre and Marie Curie-Paris 6 University, Paris, France \\ dInstitute for Metabolic Sciences, Univeristy of Cambridge School of Clinical Medicine, Cambridge, UK \\ e Clinical Center for Minimally Invasive and Bariatric Surgery, ISCARE-Lighthouse, Prague and 1st Medical Faculty, \\ Charles University, Prague, Czech Republic; representative of the International Federation for the Surgery of Obesity - European Chapter \\ ${ }^{f}$ Department of Gastroenterology and Hepatology, Academic Medical Centre, University of Amsterdam, Amsterdam, The Netherlands \\ ${ }^{g}$ Center for Metabolic Disorders in Endocrinology, Institute of Endocrinology, Diabetes and Diseases of Metabolism, \\ Clinical Center of Serbia, Belgrade, Serbia \\ ${ }^{\mathrm{h}}$ Atherosclerosis and Metabolism Unit, Soroka UMC, Ben-Gurion University SHC, Beer Sheva, Israel \\ i Clinical Center of Diabetes, Nutrition, Metabolic diseases, 'luliu Hatieganu' University, Cluj-Napoca, Romania \\ j Department of Physiology, University of Lausanne, Lausanne, Switzerland \\ k Department of Medicine, Institute for Diabetes and Metabolism, Medical University, Graz, Austria \\ ' Department of Pathophysiology, Medical University of Silesia, Katowice, Poland
}

\section{Key Words}

European guidelines - Obesity management - Primary care . OMTF

\section{Summary}

The development of consensus guidelines for obesity is complex. It involves recommending both treatment interventions and interventions related to screening and prevention. With so many publications and claims, and with the awareness that success for the individual is short-lived, many find it difficult to know what action is appropriate in the management of obesity. Furthermore, the significant variation in existing service provision both within countries as well as across the regions of Europe makes a standardised approach, even if evidence-based, difficult to implement. In formulating these guidelines, we have attempted to use an evidence-based approach while allowing flexibility for the practicing clinician in domains where evidence is currently lacking and ensuring that in treatment there is recognition of clinical judgment and of regional diversity as well as the necessity of an agreed approach by the individual and family. We conclude that i) physicians have a responsibility to recognise obesity as a disease and help obese patients with appropriate prevention and treatment, ii) treatment should be based on good clinical care and evidence-based interventions and iii) obesity treatment should focus on realistic goals and lifelong management.

\section{Introduction}

Obesity is now recognized as the most prevalent metabolic disease world-wide, reaching epidemic proportions in both developed and developing countries and affecting not only adults but also children and adolescents. The WHO has already declared obesity a global epidemic that constitutes one of the biggest current health problems [1]. In the European region, obesity also presents an unprecedented and underestimated public health challenge [2], with its prevalence rising rapidly and expected to include 150 million adults and 15 million children by 2010 .

Overweight and obesity are responsible for about $80 \%$ of cases of type 2 diabetes, $35 \%$ of ischaemic heart disease and $55 \%$ of hypertensive disease among adults in Europe. They together cause more than 1 million deaths and 12 million lifeyears of ill health each year. It is estimated that one in 13 annual deaths in the EU is likely to be related to excess weight [3]. The consequent economic implications and the burden on national health costs are quite substantial.

Despite steady progress in the management of obesity, its prevalence continues to rise, stressing the necessity for prevention and intervention strategies not only at the individual but also at the communities and the population as a whole [4].

\begin{tabular}{ll}
\hline KARGER & @ 2008 S. Karger GmbH, Freiburg \\
Fax +49 7614520714 & Accessible online at: \\
$\begin{array}{l}\text { E-mail Information@Karger.de } \\
\text { www.karger.com }\end{array}$ & www.karger.com/ofa
\end{tabular}

Constantine Tsigos, $\mathrm{MD}, \mathrm{PhD}$

EASO OMTF

231 North Gower Street, London, NW1, ZNR, UK

Tel. +44 20-7691 1900, Fax -73876033

E-mail ctsigos@gmail.com 
These European guidelines on the management of obesity in adults were developed to address the need for evidence-based recommendations for the management of obesity at the individual level and to establish a basis for a more uniform approach in obesity management across Europe. Our aim is to provide physicians, health-care policy makers and health-care carriers with essential elements of good clinical practice in the management of obesity. The working group of the European Obesity Management Task Force of the European Association for the Study of Obesity (EASO), which performed this task, was composed of experts, representing key disciplines in comprehensive obesity management and reflecting European geographical and ethnic diversity. The group also included a representative $(\mathrm{MF})$ of the International Federation for the Surgery of Obesity - European Chapter (IFSO-EC). We reviewed published national obesity guidelines [5-24] from several European countries. At the same time, we have adopted a rigorous, evidence-based approach to the development of the practice recommendations, knowing well the limitations of the obesity literature on the issues we dealt. In addition, each recommendation includes a level of evidence (1 to 4) and/or a grade (A, B, C or D) based upon the Scottish Intercollegiate Guidelines Network (SIGN) [5]. The level of evidence informs the reader about the strength of the evidence that supports each recommendation while the grade of recommendation reflects both the supporting level of evidence and a consideration, where applicable, of the harms and costs of the intervention and its importance to the individual or population (see Appendix).

\section{Definition and Classification of Obesity}

Obesity is a chronic disease characterised by an increase of body fat stores. In clinical practice, the body fatness is assessed by the body mass index (BMI). BMI is calculated as measured body weight $(\mathrm{kg})$ divided by measured height squared $\left(\mathrm{m}^{2}\right)$.

In adults (age over 18 years) obesity is defined by a BMI $\geq 30$ $\mathrm{kg} / \mathrm{m}^{2}$ and overweight (also termed pre-obesity) by a BMI between 25 and $29.9 \mathrm{~kg} / \mathrm{m}^{2}$. Many people in the overweight range of BMI $25-29.9 \mathrm{~kg} / \mathrm{m}^{2}$ will become obese in their lifetime $[1,2]$ (table 1) \{level 1$\}$.

Central adiposity is associated with metabolic and cardiovascular diseases $[1,25]$ \{level 1$\}$. The amount of abdominal fat can be assessed by waist circumference [26] \{level 2\}. Waist circumference correlates positively with abdominal fat content. The waist circumference is measured in the horizontal plane midway in the distance of the superior iliac crest and the lower margin of the last rib [27] \{level 4\}.

The most recent International Diabetes Federation consensus [28] defined central obesity (also called as visceral, android, apple-shaped or upper body obesity) in Europids as a waist circumference $\geq 94 \mathrm{~cm}$ in men and $\geq 80 \mathrm{~cm}$ in non-pregnant women $\{$ level 3 \}. Lower cut-off points for central obesity are
Table 1. BMI categories (WHO 1997)

\begin{tabular}{ll}
\hline Category & $\mathrm{BMI}, \mathrm{kg} / \mathrm{m}^{2}$ \\
\hline Underweight & $<18.5$ \\
Healthy weight & $18.5-24.9$ \\
Pre-obese state & $25.0-29.9$ \\
Obesity grade I & $30.0-34.9$ \\
Obesity grade II & $35.0-39.9$ \\
Obesity grade III & $\geq 40$ \\
\hline
\end{tabular}

proposed for South Asian $(90 \mathrm{~cm})$, Chinese $(90 \mathrm{~cm})$ and Japanese $(85 \mathrm{~cm})$ men, but higher for Japanese $(90 \mathrm{~cm})$ women. Further epidemiological studies are required for formalising appropriate cut-off points in other ethnic populations (e.g. South and Central Americans, Eastern Mediterranean and Middle East populations, Sub-Saharan Africans) \{level 4\}. In the meantime, the South Asian cut-off points should be used for the Central and South Americans, and the European cut-off points for the Sub-Saharan and South East European and Middle Eastern populations $\{$ level 4$\}$.

\section{Pathogenesis of Obesity}

The cause of obesity is complex and multi-factorial [29,30]. At the simplest level, obesity develops as a result of a period of chronic energy imbalance and is maintained by a continued elevated energy intake sufficient to maintain the acquired higher energy needs of the obese state. Complex interactions between biological (including genetic and epigenetic), behavioural, social and environmental factors (including chronic stress) are involved in regulation of energy balance and fat stores $[4,31,32]$. The rapid increase in the prevalence of obesity over the past 30 years is mainly a result of cultural and environmental influences. High energy density diet, increased portion size, low physical activity and adoption of a sedentary lifestyle as well as eating disorders are considered as important risk factors for the development of obesity [2, 4]. These behavioural and environmental factors lead to alterations in adipose tissue structure (hypertrophy and hyperplasia of adipocytes, inflammation) and secretion (e.g. adipokines) [33, 34].

\section{Epidemiology of Overweight and Obesity in Europe}

The prevalence of obesity in Europe is in the range 10-25\% in men and $10-30 \%$ in women (fig. 1) [2, 4]. In the past 10 years the prevalence of obesity has increased by $10-40 \%$ in the majority of European countries. In most countries more than $50 \%$ of people are overweight or obese. The prevalence of obesity was higher among men than among women in 14 of 36 countries or regions with data for both genders, and the prevalence of overweight was higher among men in all 36 countries [4]. 
Fig. 1. Prevalence of obesity and overweight in Europe (Source: International Obesity Task Force (IOTF)).

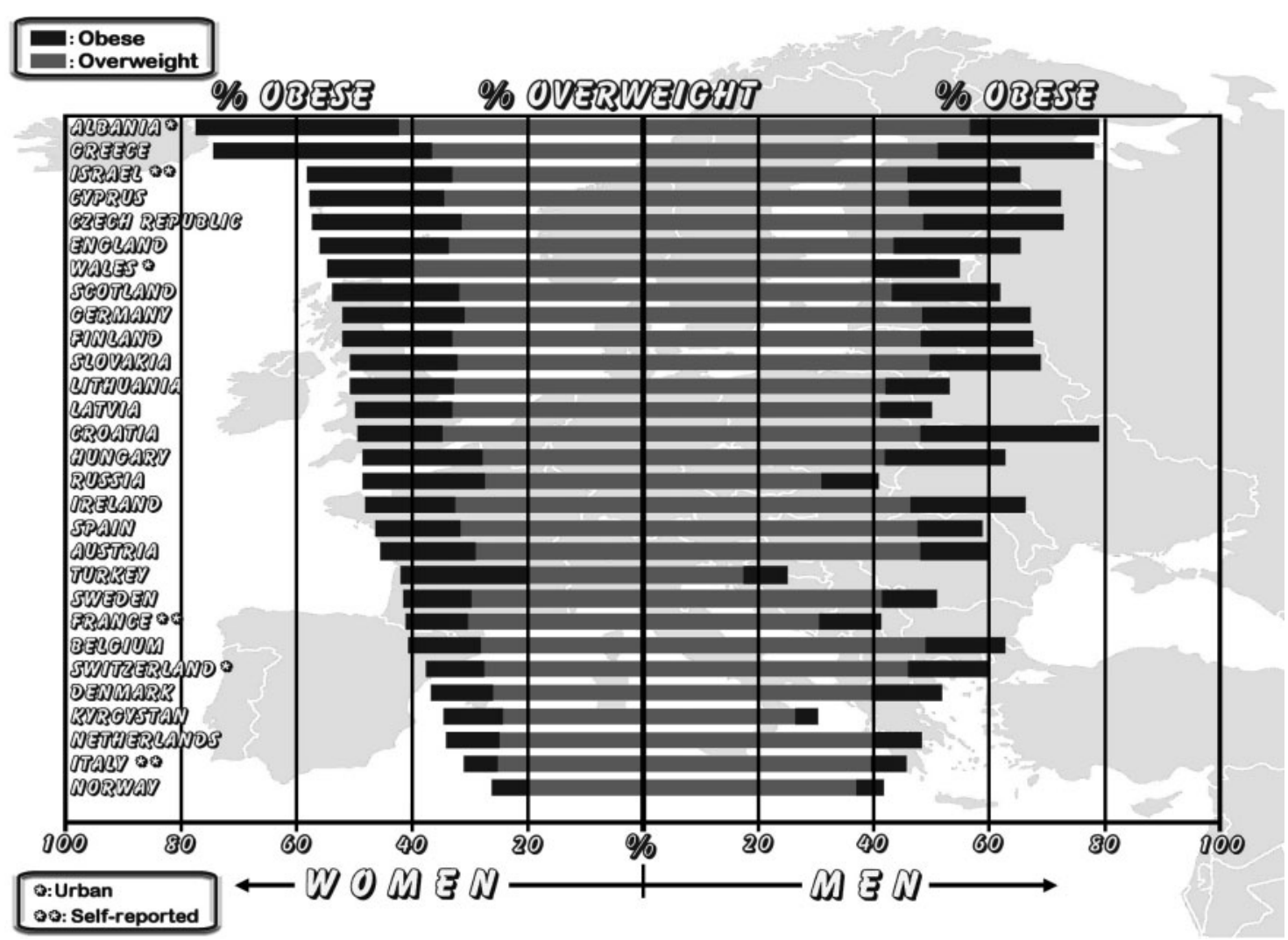

\section{Health Risks of Obesity and Socio-Economic Consequences of Obesity}

Obesity causes a significantly increased morbidity, disability and mortality and impairs quality of life (table 2) [3, 35-40] \{level 1$\}$. Obesity is associated with an increased risk of death from both cardiovascular diseases and certain cancers, particularly with higher levels of obesity. In the BMI range 25-30 $\mathrm{kg} / \mathrm{m}^{2}$ (overweight), the link to increased mortality is weaker and may be more greatly influenced by fat distribution. The association between obesity and mortality weakens with increasing age, especially over 75 years.

The increased health risks translate into an increased burden on the health-care system. Direct health-care costs due to obesity in Europe are estimated to account for up to $7 \%$ of total health-care costs, which is comparable to diseases such as cancer [4] \{level 2\}.

\section{Examination of the Obese Patient}

A comprehensive history relevant to the patient's obesity should be obtained; this will include the onset of and previous treatment for obesity $\{R B P\}$.

Other important issues to consider include $[32,41-44]\{R B P\}$ :

- ethnicity,

- family history,
- dietary habits, eating pattern and possible presence of an eating disorder (binge eating, binge eating disorder, night eating syndrome, bulimia),

- presence of depression and other mood disorders,

- physical activity,

- other determinants, e.g. genetic, drugs, endocrine abnormalities, psychosocial factors, chronic stress, smoking cessation, etc.,

- health consequences of obesity (see table 2),

- patient expectations and motivation for change.

\section{Physical Examination}

- Measure weight and height (from which BMI is calculated), waist circumference, blood pressure (appropriate sizecuff) $\{$ grade 3$\}$.

- Assess the presence and impact of obesity-related diseases (diabetes, hypertension, dyslipidaemia, cardiovascular, respiratory, joint diseases, non-alcoholic fatty liver disease (NAFLD), sleep disorders etc.) $\{R B P\}$.

- Look for the presence of acanthosis nigricans as a sign of insulin resistance $\{R B P\}$.
Tsigos/Hainer/Basdevant/Finer/Fried/ Mathus-Vliegen/Micic/Maislos/Roman/Schutz/ Toplak/Zahorska-Markiewicz 
Table 2. Obesity-related health risks and complications

Metabolic complications
Diabetes, insulin resistance
Dyslipidaemia
Metabolic syndrome
Hyperuricaemia, gout
Low-grade inflammation
Cardiovascular disorders
Hypertension
Coronary heart disease (CHD)
Congestive heart failure
Stroke
Venous thromboembolism
Respiratory disease
Asthma
Hypoxemia
Sleep apnoea syndrome
Obesity hypoventilation syndrome (OHS) (Pickwickian syndrome)
Cancers
Oesophagus, small intestine, colon, rectum, liver, gallbladder, pancreas,
kidney, leukaemia, multiple myeloma, and lymphoma
In women: endometrial, cervix uteri, ovary, breast cancer after
menopause
In men: prostate

Osteoarthritis ( knee) and an increase in pain in the weight bearing joints

Gastro intestinal

Gallbladder disease

Non-alcoholic fatty liver disease (NAFLD) or non-alcoholic steatohepatitis (NASH)

Gastro-esophageal reflux

Hernia

Urinary incontinence

Reproductive health

Menstrual irregularity, infertility, hirsutism, polycystic ovaries Miscarriage

Gestational diabetes, hypertension, preeclampsia,

Macrosomia, foetal distress, malformation (i.e. neural tube defect)

Dystocia and primary caesarean section

Miscellaneous

Idiopathic intracranial hypertension

Proteinuria, nephrotic syndrome

Skin infection

Lymphoedema

Complications from anaesthesia

Periodontal disease

Psychological and social consequences

Low self-esteem

Anxiety and depression

Stigmatisation

Discrimination in employment, college acceptance, job earning etc.

*The specific levels of risk associated with obesity vary with age, gender, ethnicity and social conditions.

\section{Laboratory Examinations}

The minimum dataset required will include $\{R B P\}$ :

- fasting blood glucose,

- serum lipid profile (total, HDL and LDL cholesterol, triglycerides),

- uric acid,

- thyroid function (TSH level),

- liver function (hepatic enzymes).

Cardiovascular assessment, if indicated $\{R B P\}$.

Endocrine evaluation if Cushing's syndrome or hypothalamic disease suspected.

Liver investigation (ultrasound, biopsy) if abnormal liver function tests suggest NAFLD or other liver pathology.

\section{Body Composition Analysis}

Waist circumference can be used as a proxy for abdominal fat [26] \{level 3; RBP . Assessment of body composition is not essential for the management of obesity in clinical practice. Uncertainty exists about the validity of body composition and/or measured changes in weight loss by bedside techniques such as bioelectrical impedance analysis (BIA), particularly in obese individuals [45]. Dual X-ray absorptiometry (DXA) is the more relevant method for body composition assessment in specialist centres: it can be useful in the clinical evaluation of obesity associated with a dramatic decrease in lean body mass (i.e. obesity associated with genetic, endocrinological or neurologiocal disorders and follow-up of bariatric surgery) [45].

\section{Comprehensive Obesity Management}

Appropriate goals of weight management emphasise realistic weight loss to achieve a reduction in health risks and should include promotion of weight loss, maintenance and prevention of weight regain (fig. 2) $\{R B P\}$. Patients should understand that, since obesity is a chronic disease, weight management will need to be lifelong.

\section{Aims of Treatment}

\section{Management and Treatment of Obesity (fig. 2)}

The management and treatment of obesity have wider objectives than weight loss alone and include risk reduction and health improvement. These may be achieved by modest weight loss (i.e. $5-10 \%$ of initial body weight), improved nutritional content of the diet and modest increases in physical activity and fitness $[43,46,47]$ \{level 1$\}$.

Appropriate management of obesity complications in addition to weight management should include $[48,49]$ \{level 1; grade A\}: 
Table 3. A guide to deciding the initial level of intervention to discuss with the patient

\begin{tabular}{|c|c|c|c|}
\hline \multirow[t]{2}{*}{ BMI, $\mathrm{kg} / \mathrm{m}^{2 *}$} & \multicolumn{2}{|c|}{ Waist circumference, $\mathrm{cm}^{*}$} & \multirow[t]{2}{*}{ Co-morbidities } \\
\hline & $\begin{array}{l}\text { Men }<94 \\
\text { Women }<80\end{array}$ & $\begin{array}{l}\text { Men } \geq 94 \\
\text { Women } \geq 80\end{array}$ & \\
\hline $25.0-29.9$ & $\mathrm{~L}$ & $\mathrm{~L}$ & $\mathrm{~L} \pm \mathrm{D}$ \\
\hline $30.0-34.9$ & $\mathrm{~L}$ & $\mathrm{~L} \pm \mathrm{D}$ & $\mathrm{L} \pm \mathrm{D}$ \\
\hline $35.0-39.9$ & $\mathrm{~L} \pm \mathrm{D}$ & $\mathrm{L} \pm \mathrm{D}$ & $\mathrm{L} \pm \mathrm{D} \pm \mathrm{S}$ \\
\hline$\geq 40.0$ & $\mathrm{~L} \pm \mathrm{D} \pm \mathrm{S}$ & $\mathrm{L} \pm \mathrm{D} \pm \mathrm{S}$ & $\mathrm{L} \pm \mathrm{D} \pm \mathrm{S}$ \\
\hline
\end{tabular}

$\mathrm{L}=$ Lifestyle intervention (diet and physical activity) $\mathrm{D}=$ consider drugs; $\mathrm{S}=$ consider surgery

*BMI and waist circumference cut-off points are different for some ethnic groups.

- management of dyslipidaemia,

- optimising glycaemic control in type 2 diabetics,

- normalising blood pressure in hypertension,

- management of pulmonary disorders, such as sleep apnoea syndrome (SAS),

- attention to pain control and mobility needs in osteoarthritis,

- management of psychosocial disturbances, including affective disorders, eating disorders, low self esteem and body image disturbance.

Obesity management may reduce the need to treat co-morbidities by drugs $[48,50]\{$ level 1$\}$.

\section{Prevention of Further Weight Gain}

In some patients, especially in those with overweight (BMI $25.0-29.9 \mathrm{~kg} / \mathrm{m}^{2}$ ), prevention of further weight gain (through dietary advice and increase in physical activity) rather than weight loss per se may be an appropriate target (table 3) $\{R B P\}$.

Weight loss objectives should be:

- realistic,

- individualised,

- aimed at the long term.

Practical weight loss objectives are:

- A 5-15\% weight loss over a period of 6 months is realistic and of proven health benefit $[51,52]$ \{level 1$\}$.

- A greater (20\% or more) weight loss may be considered for those with greater degrees of obesity $\left(\mathrm{BMI} \geq 35 \mathrm{~kg} / \mathrm{m}^{2}\right.$ ) $\{R B P\}$.

- Maintenance of weight loss and prevention and treatment of co-morbidities are the two main criteria for success.

\section{Failure to Lose and Maintain Weight}

- Consider referral to an obesity specialist in case the patient fails to lose weight in response to the prescribed intervention (fig. 2).
- Weight cycling, defined by repeated loss and regain of body weight, is more frequent in women and may be linked to increased risk for hypertension, dyslipidaemia and gallbladder disease [54]. It has been associated with psychological distress and depression and may require appropriate psychological care and/or antidepressant therapy [55].

\section{Follow-Up}

Obesity is a chronic disease. Follow-up and continued supervision is necessary [56] to:

- prevent weight regain $\{$ level 2$\}$,

- monitor disease risks and treat co-morbidities (e.g. type 2 diabetes mellitus, cardiovascular disease) $\{R B P\}$.

\section{Specific Components of Treatment}

\section{Diet}

The use of self-recorded food diary allows a qualitative assessment of the diet. In addition, it can be used to help the patient identify perceptions and beliefs about emotional eating behaviour (cognition) and eating habits (behaviour) $\{R B P\}$.

Dietary advice should encourage healthy eating and emphasise the need to increase consumption of grain, cereals and fibre as well as vegetables and fruit, and to substitute low-fat dairy products and meats for full- or high-fat alternatives [49, 57-59] \{level 1, 2; grade B\}.

An appropriate dietary regimen can be achieved in a number of ways:

General Advice $\{$ grade 3, 4$\}$

- Decrease energy density of foods and drinks.

- Decrease the size of food portions.

- Avoid snacking between meals.

- Do not skip breakfast and avoid eating in the night time.

- Manage and reduce episodes of loss of control or binge eating.

\section{Specific Advice}

Energy (calorie) restriction should be individualised and take account of nutritional habits, physical activity, co-morbidities and previous dieting attempts $\{R B P\}$.

An emphasis put on the macronutrient proportion in the various diets (low fat, low carbohydrate, or high protein, etc.) has not proved better than a classic hypocaloric diet, except for low-glycaemic load diets (carbohydrate content of the diet $x$ glycaemic index) in the short term [60-63] \{level 2.3\}. Prescribing an energy-restricted diet may require the intervention of a nutritionist (dietitian).

- A $15-30 \%$ decrease in energy (calorie) intake from habitual intake in a weight-stable individual is sufficient and appropriate. However, underreporting of energy intake by 


\section{Clinical care pathway for overweight and obese adults}

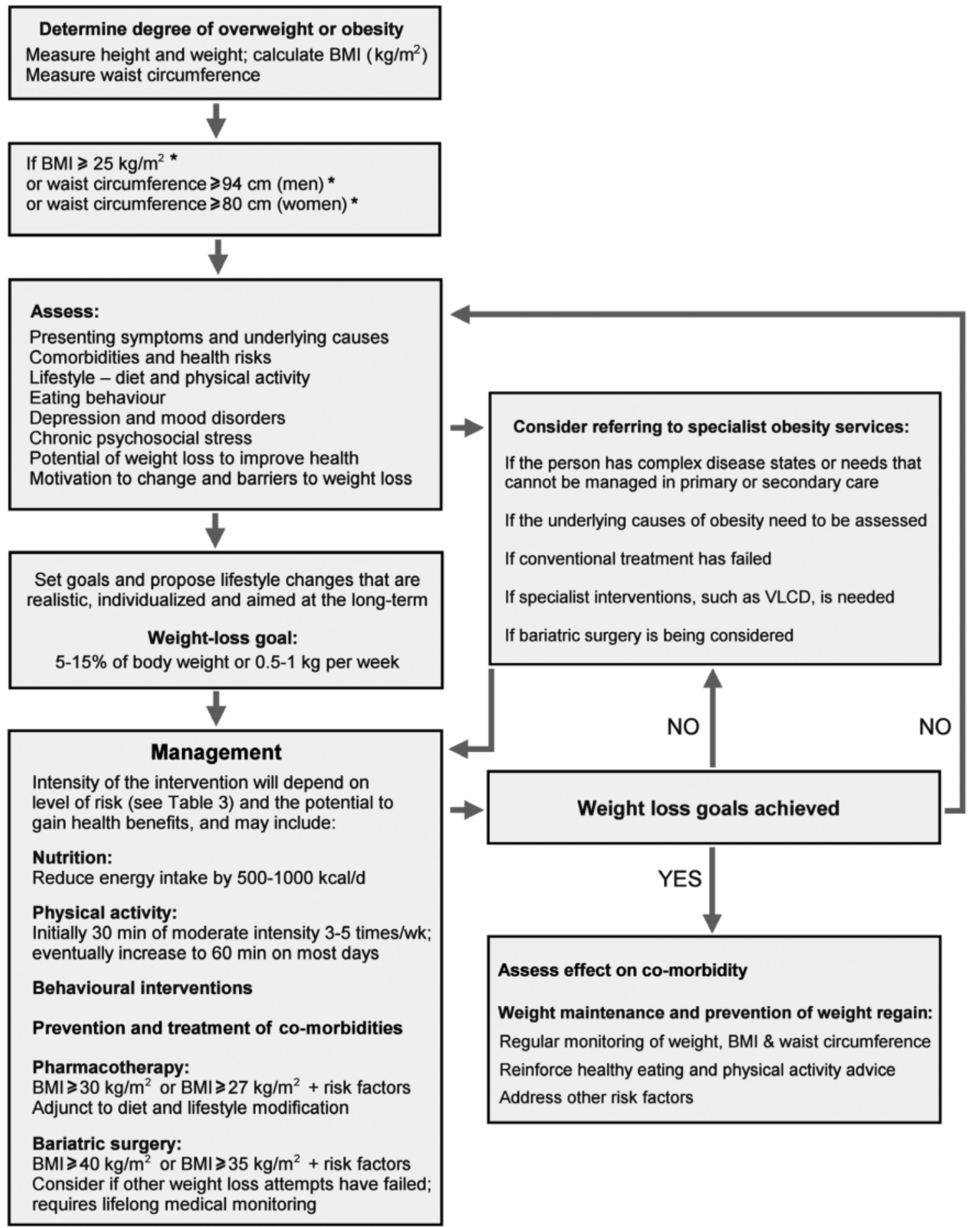

Fig. 2. Algorithm for the assessment and stepwise management of overweight and obese adults. *BMI and waist circumference cutoff points are different for some ethnic groups (see text). calate BMI $\left(\mathrm{kg} / \mathrm{m}^{2}\right)$

If $\mathrm{BMI} \geqslant 25 \mathrm{~kg} / \mathrm{m}^{2}$ *

waist circumference

Assess:

Comorbidities and health risks

- diet and physical activity

Depression and mood disorders

Set goals and propose lifestyle changes that are realistic, individualized and aimed at the long-term

Weight-loss goal:

$5-15 \%$ of body weight or $0.5-1 \mathrm{~kg}$ per week

\section{Management}

Intensity of the intervention will depend on level of risk (see Table 3 ) and the potential to gain health benefits, and may include:

Nutrition:

Physical activity:

nitially 30 min of moderate intensity 3-5 times/wk;

Behavioural interventions

Pharmacotherapy:

$\mathrm{BMI} \geqslant 30 \mathrm{~kg} / \mathrm{m}^{2}$ or $\mathrm{BMI} \geqslant 27 \mathrm{~kg} / \mathrm{m}^{2}$ + risk factors

Adjunct to diet and lifestyle modification obese patients is common. There is a great variation in energy requirements between the individuals which is dependent on individual's gender, age, BMI and physical activity level. Tables predicting energy requirements taking into account gender, age, BMI and physical activity ratio can be used. An easy rule of thumb is a daily energy requirement of $25 \mathrm{kcal} / \mathrm{kg}$ for either gender but, for the same body weight, this creates a greater energy deficit in men. The recommended weight-reducing dietary regimen tailored to an individual's need usually provides an energy deficit of $600 \mathrm{kcal} /$ day grade $A, B$. Thus for an obese sedentary woman with a BMI of $32 \mathrm{~kg} / \mathrm{m}^{2}$ and with an estimated daily intake of $2,100 \mathrm{kcal}(8,800 \mathrm{~kJ})$, a diet prescribing $1,400-1,600 \mathrm{kcal}(6,000-7,000 \mathrm{~kJ})$ would be appropriate. A $600 \mathrm{kcal}(2,600 \mathrm{~kJ})$ daily deficit will predict a weight loss of about $0.5 \mathrm{~kg}$ weekly $[59,64]$ \{level 2$\}$. Diets providing 1,200 $\mathrm{kcal} /$ day or more are classified as hypocaloric balanced diets (HBD) or balanced deficit diets [52]. 
- The use of very low calorie (liquid) diets (VLCD) (less than $800 \mathrm{kcal} /$ day; 3,500 kJ/day) may form part of a comprehensive programme undertaken by an obesity specialist or other physician trained in nutrition and dietetics $\{R B P\}$. However, their administration should be limited for specific patients and for short periods of time [65]. VLCDs are unsuitable as a sole source of nutrition for infants and children, adolescents, pregnant or lactating women and the elderly.

- The energy content of low calorie diets (LCD) presented as a total diet composed of meal replacements is specified as between 800 and 1,200 kcal/day [65, 66]. Diets providing $1,200 \mathrm{kcal} /$ day or more are classified as hypocaloric balanced diets (HBD) or balanced deficit diets [52].

Diets providing less than $1,200 \mathrm{kcal} /$ day $(5,000 \mathrm{~kJ} /$ day $)$ might yield micronutrient deficiencies, which could exert untoward effects not only on nutritional status but also on the weight management outcome. Meal replacement diets (substitution of one or two daily meal portions by VLCD) may contribute to nutritionally well-balanced diet and weight loss maintenance [66] \{level 2\}.

\section{Cognitive Behavioural Approaches}

Cognitive Behavioural Therapies (CBT) are techniques which aim to help a patient modify both his/her insight and understanding of thoughts and beliefs concerning weight regulation, obesity and its consequences; they also directly address behaviours that require change for successful weight loss and weight loss maintenance. CBT includes several components such as self-monitoring (e.g. dietary record), techniques controlling the process of eating, stimulus control as well as re-inforcement, cognitive and relaxation techniques [67]. CBT elements should form part of routine dietary management or, as a fuller, structured programme, form the basis of specialist intervention $\{$ grade $B\}$. This care can be in part delivered in a group setting or through bibliotherapy using self-help manuals. CBT should be provided not only by registered psychologists but also by other trained health professionals such as physicians, dieticians, exercise physiologists or psychiatrists $\{R B P\}$.

\section{Physical Activity}

Besides increasing energy expenditure and promoting fat loss, physical activity has additional benefits [68-74]. Physical activity:

- reduces abdominal fat and increases lean (muscle and bone) mass $\{$ level 2$\}$,

- may attenuate the weight loss-induced decline of resting energy expenditure $\{$ level 2$\}$,

- reduces blood pressure and improves glucose tolerance, insulin sensitivity and lipid profile $\{$ level 1$\}$,

- improves physical fitness \{level 1\},

- improves compliance to the dietary regimen and has a positive influence on the long-term weight maintenance $\{$ level 2\},
- improves feeling of well-being and self-esteem $\{$ level 2$\}$,

- reduces anxiety and depression \{level 2$\}$.

The objective should also be to reduce sedentary behaviour (e.g. television viewing and computer use) and increase daily activities (e.g. walking or cycling instead of using a car, climbing stairs instead of using elevators). Patients should be advised and helped in undertaking (or increasing) physical activity \{rade $A\}$. Exercise advice must be tailored to the patient's ability and health and focus on a gradual increase to levels that are safe $\{R B P\}$. Current recommendations suggest that people of all ages should undertake 30-60 min of physical activity of moderate intensity (such as brisk walking) on most, if not all, days of the week $[72,75]$ \{level 2; grade $B\}$.

\section{Psychological Support}

Physicians should recognise where psychological or psychiatric issues interfere with successful obesity management, e.g. depression $\{R B P\}$. Psychological support and/or treatment will then form an integral part of management, and in special cases (anxiety, depression and stress) referral to a specialist may be indicated. Self-help lay groups and the support of the obesity treatment group may all be useful in this setting $\{R B P\}$.

\section{Pharmacological Treatment}

- Pharmacological treatment should be considered as part of a comprehensive strategy of disease management $[49,76]$ $\{R B P\}$.

- Pharmacotherapy can help patients to maintain compliance, ameliorate obesity-related health risks and improve quality of life. It can also help to prevent the development of obesity co-morbidities (e.g. type 2 diabetes mellitus) [77, 78] \{level 2\}.

- Current drug therapy is recommended for patients with a $\mathrm{BMI} \geq 30 \mathrm{~kg} / \mathrm{m}^{2}$ or a BMI $\geq 27$ with an obesity-related disease (e.g. hypertension, type 2 diabetes mellitus) $[49,76]$ $\{R B P\}$.

- Drugs should be used according to their licensed indications and restrictions $\{R B P\}$.

- The efficacy of pharmacotherapy should be evaluated after the first 3 months. If weight loss achieved is satisfactory ( $>5 \%$ weight loss in non-diabetic and $>3 \%$ in diabetic patients), treatment should be continued. Treatment should be discontinued in non-responders $\{R B P\}$.

\section{Criteria for Drug Choice 2008}

Of the three drugs licensed and recommended for use within the EU (orlistat, sibutramine, rimonabant), few data exist to allow an evidence-based choice for the individual patient. All three drugs produce moderate and broadly similar absolute and placebo-subtracted weight losses [79-84] \{level 2\}. There are some differences in the licensed indications. Currently, choice is largely determined by excluding drugs for which there are specific contra-indications (e.g. orlistat: chronic mal- 
Table 4. Levels of evidence, grades of recommendation and good practise points
Definition

Levels of evidence

$1 \quad{ }^{1++}$ high-quality meta-analyses, systematic reviews of RCTs, or RCTs with a very low risk of bias $1^{+}$well-conducted meta-analyses, systematic reviews of RCTs, or RCTs with a low risk of bias

$1^{-}$Meta-analyses, systematic reviews of RCTs, or RCTs with a high risk of bias

$2 \quad{ }^{2++}$ high-quality systematic reviews of case-control or cohort or studies

$2^{+}$high-quality case-control or cohort studies with a very low risk of confounding, bias, or chance and a high probability that the relationship is casual

$2-$ well-conducted case control or cohort studies with a low risk of confounding, bias, or chance and a moderate probability that the relationship is casual

non-analytic studies, e.g. case reports, case series

expert opinion

Grades of recommendation

A at least one meta-analysis, systematic review, or RCT rated as $1^{++}$, and directly applicable to the target population; or a systematic review of RCTs or a body of evidence consisting principally of studies rated as $1^{+}$, directly applicable to the target population, and demonstrating overall consistency of results

B a body of evidence including studies rated as $2^{++}$, directly applicable to the target population, and demonstrating overall consistency of results; or extrapolated evidence from studies rated as $1^{++}$, or $1^{+}$

C a body of evidence including studies rated as $2^{+}$, directly applicable to the target population, and demonstrating overall consistency of results; or

Extrapolated evidence from studies rated as $2^{++}$

$\mathrm{D}$

evidence level 3 or 4 ; or

extrapolated evidence from studies rated as $2^{+}$

Good practice points

RBP recommended best practise based on the clinical experience of the guideline development group

absorption syndrome and cholestasis; sibutramine: psychiatric illness, concomitant use of monoamine oxidase inhibitors or of other centrally acting drugs for the treatment of psychiatric disorders, history of coronary artery disease, inadequately controlled hypertension $>145 / 90 \mathrm{~mm} \mathrm{Hg}$; rimonabant: history of treatment of major depressive illness and/or ongoing antidepressive treatment, severe hepatic or renal impairment) $\{R B P\}$. For full details see product specifications.

\section{Surgery}

Surgery is the most effective treatment for morbid obesity in terms of long-term weight loss [85-87] \{level 2\}, improves comorbidities and quality of life [88] \{level 2$\}$, and in the long term decreases overall mortality $[89,90]$ \{level 2$\}$. Surgery should be considered for patients in age groups from 18-60 years with a BMI $\geq 40.0$ or with BMI between 35.0 and 39.9 $\mathrm{kg} / \mathrm{m}^{2}$ and co-morbidities in whom surgically induced weight loss is expected to improve the disorder (such as type 2 diabetes and other metabolic disorders, cardiorespiratory disease, severe joint disease and obesity-related severe psychological problems) [20] \{rrade 3, 4\}. BMI criterion may be the current BMI or a documented previous BMI of this severity [20].

Multi-disciplinary skills are needed to support surgical interventions. Patients should only be referred to units able to assess patients prior to surgery, able to offer a comprehensive approach to diagnosis and assessment and treatment, and able and willing to provide long-term follow-up \{grade 2.3\}. The referring physician and the inter-disciplinary team should collaborate closely to optimise the long-term post-operative care $\{R B P\}$.

A laparoscopic technique should be considered as the first treatment choice in bariatric surgery [91] $\{R B P\}$. In all situations the bariatric surgeon's experience is a key issue for a successful outcome. It is not advisable to perform bariatric techniques on an occasional basis.

Today, the most common surgical techniques are:

- food limitation operations (restrictive procedures) such as adjustable gastric banding (AGB), proximal gastric bypass (GBP) and sleeve gastrectomy (SG),

- operations limiting absorption of macronutrients (limiting energy absorption) such as biliopancreatic diversion (BPD),

- combined operations such as biliopancreatic diversion with duodenal switch (BPD-DS) or distal gastric bypass.

The expected average weight loss and long-term weight maintenance is increasing with the following procedures: AGB, SG, GBP, BPD-DS, BPD [86, 87]. However, the surgical complexity and potential surgical and long-term nutritional risks of the procedures increase in the same order [85, 87]. 


\section{Alternative Therapies}

Obesity treatment is often unsuccessful. As a result, unorthodox and unproven treatments flourish and are often offered. There is insufficient evidence to recommend in favour of herbal medicines, dietary supplements or homoeopathy for obesity management in the obese person. Physicians should advise patients to follow evidence-based treatments and recommend treatments only where evidence of safety and efficacy has been established $\{R B P\}$.

\section{Developing a Health-Care Team for a Weight Management Programme}

The development of networks of care involving the general practitioner, obesity specialist, nutritionist (dietician), exercise physiologist (physiatrist), behavioural therapist (psychologist/psychiatrist) and often patient support groups is encouraged $\{R B P\}$.

No health-care system can provide treatment for all those who are obese and overweight. Support groups, commercial and lay organisations, books and other media can provide useful help and support; the advice they give should conform to the principles of these guidelines $\{R B P\}$.

\section{Conclusion}

- Physicians have a responsibility to recognise obesity as a disease and help obese patients with appropriate treatment.

- Treatment should be based on good clinical care and evidence-based interventions.

- Obesity treatment should focus on realistic goals and lifelong management.

\section{Appendix}

\section{Levels of Evidence and Grades of Recommendation}

The evidence for the guidance given is drawn from a number of systematic reviews listed in the references. The grading system is based upon the Scottish Intercollegiate Guidelines Network (SIGN), but has been simplified by amalgamating subcategories of each level into a single criterion (table 4).

\section{References}

1 WHO: Obesity: Preventing and managing the global epidemic. Report of a WHO consultation. Geneva, WHO Technical Report Series 894, 2000.

2 James WP: The epidemiology of obesity: the size of the problem. J Intern Med 2008;263:336-52.

3 Banegas JR, López-García E, Gutiérrez-Fisac JL, Guallar-Castillón P, Rodríguez-Artalejo F: A simple estimate of mortality attributable to excess weight in the European Union. Eur J Clin Nutr 2003;57:201-8.

4 Branca F, Nikogosian H, Lobstein T (eds): The challenge of Obesity in the WHO European Region and the Strategies for Response: Summary. Copenhagen, WHO Regional Office for Europe, 2007.

5 Scottish Intercollegiate Guidelines Network: Obesity in Scotland. Integrating Prevention with Weight Management. A National Clinical Guideline Recommended for Use in Scotland. Edinburgh, Scottish Intercollegiate Guidelines Network, 1996.

6 Hainer V, Kunesova M, Parizkova J, Stich V, Slaba S, Fried M, Malkova I: Clinical guidelines for diagnosis and management of obesity in the Czech Republic. Sborn Lek 1998;99:235-250.

7 Royal College of Physicians: Clinical Management of Overweight and Obese Patients with Particular Reference to the Use of Drugs. London, Royal College of Physicians, 1998.

8 Lauterbach K, Wirth A, Westenhofer J, Hauner H: Evidenz-basierte Leitlinie zur Behandlung der Adipositas in Deutschland. Köln, Hauser, 1998.

9 Consensus sur le traitement de l'obesité en Suisse. Schweiz Med Wochenschr 1999;129(suppl 114): 21S-36S. Revised version 2006 to be downloaded on www.asemo.ch
10 Spanish Society for the Study of Obesity (Sociedad Española para el Estudio de la Obesidad,SEEDO): Consensus SEEDO'2000 for the Evaluation of Overweight and Obesity and the Establishment of Criteria for Therapeutic Intervention. Barcelona, Spanish Society for the Study of Obesity (Sociedad Española para el Estudio de la Obesidad,SEEDO), 2000.

11 Hancu N, Roman G, Simu D, Miclea S (eds): Guidelines for the Management of Obesity and Overweight in Adults. Cluj-Napoca, Romanian Association for the Study of Obesity, 2001.

12 Dutch Association for the Study of Obesity: Guidelines for General Practitioners for the Treatment of Obesity: A Stepwise Approach. Amsterdam, Dutch Association for the Study of Obesity, 2001.

13 Muls E (ed): Obésité - Le consensus du BASO (Belgian Association for the Study of Obesity) Un guide pratique pour l'évaluation et le traitement de l'excés de poids, BASO, Leuven, 2001.

14 Basdevant A, Laville M, Ziegler O; Association Française d'Etudes et deRecherches sur l'Obésité (AFERO); Association de Langue Française pour l'Etude du Diabète et des Maladies Metaboliques (ALFEDIAM); Société de Nutrition et de Diététique de Langue Française (SNDLF): Recommendations for the diagnosis, the prevention and the treatment of obesity. Diabetes Metab 2002;28: 146-50.

15 Committee of the Royal College of Physicians of London: Anti-Obesity Drugs: Guidance on Appropriate Prescribing and Management. Report of the Nutrition Committee of the Royal College of Physicians of London. London, RCP, 2003.

16 Health Council of the Netherlands: Overweight and Obesity. The Hague, Health Council of the Netherlands, 2003, Report 2003/07.
17 Laville M, Romon M, Chavrier G, Guy-Grand B, Krempf M, Chevallier JM, Marmuse JP, Basdevant A: Recommendations regarding obesity surgery. Obes Surg 2005;15:1476-80.

18 The NICE Clinical Guideline CG43: Obesity: the Prevention, Identification, Assessment and Management of Overweight and Obesity in Adults and Children. December 2006. www.nice.org.uk/ guidance/index.jsp?action $=b y I D \& o=11000$.

19 CBO Quality Institute of Health Care: Guideline Diagnosis and Treatment of Obesity in Adults and Children. Utrecht, CBO, 2007/2008.

20 Fried M, Hainer V, Basdevant A, Buchwald H, Deitel M, Finer N, Greve JW, Horber F, MathusVliegen E, Scopinaro N, Steffen R, Tsigos C, Weiner R, Widhalm K: Interdisciplinary European guidelines on surgery of severe obesity. Obesity Facts 2008;1:52-58.

21 Executive summary of the clinical guidelines on the identification, evaluation and treatment of overweight and obesity in adults. Arch Intern Med 1998; 158:1855-1867.

22 National Institutes of Health (NIH), National Heart, Lung, and Blood Institute (NHLBI): The practical guide: identification, evaluation, and treatment of overweight and obesity in adults. Bethesda, National Institutes of Health, 2000; NIH publication 00-4084. www.nhlbi.nih.gov/guidelines/obesity/ ob_home.htm.

23 Lau DCW, Douketis JD, Morrison KM, Hramiak IM, Sharma AM, Ur E, for members of the Obesity Canada Clinical Practice Guidelines Expert Panel. 2006 Canadian clinical practice guidelines on the management and prevention of obesity in adults and children. Executive summary. CAMJ 2007;176 (suppl 8):S1-13. 
24 Sauerland S, Angrisani L, Belachew M, Chevallier JM, Favretti F, Finer N,Fingerhut A, Garcia Caballero M, Guisado Macias JA, Mittermair R, Morino M, Msika S, Rubino F, Tacchino R, Weiner R, Neugebauer EA: Obesity surgery: evidencebased guidelines of the European Association for Endoscopic Surgery (EAES). Surg Endosc 2005;19: 200-21.

25 Zhu S, Wang Z, Heshka S, Heo M, Faith MS, Heymsfield SB: Waist circumference and obesityassociated risk factors among whites in the third National Health and Nutrition Examination Survey: clinical action thresholds. Am J Clin Nutr 2002; 76:743-9.

26 Janssen I, Heymsfield SB, Allison DB, Kotler DP, Ross R: Body mass index and waist circumference independently contribute to the prediction of nonabdominal, abdominal subcutaneous, and visceral fat. Am J Clin Nutr 2002;75:683-8.

27 Lohman TG, Roche AF, Martello R: Anthropometric Standardization Reference Manual. Champaign, Human Kinetics, 1988.

28 Alberti KG, Zimmet PZ, Shaw J: The metabolic syndrome - a new worldwide definition. Lancet 2005;366:1059-62.

29 Yanovski SZ, Yanovski JA. Obesity. N Engl J Med 2002;21;346:591-602.

30 Haslam DW, James WP: Obesity. Lancet 2005;366: 1197-209.

31 Farooqi S, O'Rahilly S: Genetics of obesity in humans. Endocr Rev 2006;27:710-18.

32 Kyrou I, Chrousos GP, Tsigos C: Stress, visceral obesity, and metabolic complications. Ann N Y Acad Sci 2006;1083:77-110.

33 Ailhaud G: Adipose tissue as a secretory organ: from adipogenesis to the metabolic syndrome. $\mathrm{C} \mathrm{R}$ Biol 2006;329:570-7.

-34 Tilg H, Moschen AR: Adipocytokines: mediators linking adipose tissue, inflammation and immunity. Nat Rev Immunol 2006;6:772-83.

35 Adams KF, Schatzkin A, Harris TB, Kipnis V, Mouw T, Ballard-Barbash R, Hollenbeck A, Leitzmann MF: Overweight, obesity and mortality in a large prospective cohort of persons 50 to 71 years old. N Engl J Med 2006;355:763-78.

36 Flegal KM, Graubard BI, Williamson DF, Gail MH Cause-specific excess death associated with underweight, overweight and obesity. JAMA 2007;298: 2028-37.

37 Renehan AG, Tyson M, Egger M, Heller RF, Zwahlen M: Body-mass index and incidence of cancer: a systematic review and meta-analysis of prospective observational studies. Lancet. 2008;371: 569-78.

38 Stevens J, Cai J, Evenson KR, Thomas R: Fitness and fatness as predictors of mortality from all causes and from cardiovascular disease in men and women in the Lipid Research Clinics Study. Am J Epidemiol 2002;156:832-841.

39 Roberts RE, Deleger S, Strawbridge WJ, Kaplan GA: Prospective association between obesity and depression: evidence from the Alameda County Study. Int J Obes Relat Metab Disord 2003;27: 514-21.

40 Linde JA, Jeffery RW, Levy RL, Sherwood NE, Utter J, Pronk NP, Boyle RG: Binge eating disorder, weight control self-efficacy, and depression in overweight men and women. Int J Obes Relat Metab Disord 2004;28:418-25.

41 Leslie WS, Hankey CR, Lean ME: Weight gain as an adverse effect of some commonly prescribed drugs: a systematic review. Q J Med 2007;100: 395-404.
42 Malone M: Medications associated with weight gain. Ann Pharmacoth 2005;39:2046-55.

43 Slentz CA, Duscha BD, Johnson JL, Ketchum K, Aiken LB, Samsa GP, Houmard JA, Bales CW, Kraus WE: Effects of the amount of exercise on body weight, body composition, and measures of central obesity: STRRIDE - a randomized controlled study. Arch Intern Med 2004;164:31-9.

44 American Diabetes Association, American Psychiatric Association, American Association of Clinical Endocrinologist and North American Association for the Study of Obesity: Consensus Development Conference on Antipsychotic Drugs and Obesity and Diabetes Consensus Statement. Diabetes Care 2004;27: 596-601.

45 Kyle US, Bosaeus I, De Lorenzo AD, Deurenberg P, Elia M, Gomes JM, Heitmann BL, Kent-Smith L, Melcior J-C, Pirlich M, Scharfetter H, Schols AMWJ, Pichard C: Bioelectrical impedance analysis - part II: utilization in clinical practice. Clin Nutr 2004:23:1430-1453.

46 Pietrobelli A, Heymsfield SB: Establishing body composition in obesity. J Endocrinol Invest 2002;25: 884-92.

47 Knowler WC, Barrett-Connor E, Fowler SE, Hamman RF, Lachin JM, Walker EA, Nathan DM; Diabetes Prevention Program Research Group: Reduction in the incidence of type 2 diabetes with lifestyle intervention or metformin. N Engl J Med 2002;346:393-403.

48 Schwarz PE, Lindström J, Kissimova-Scarbeck K, Szybinski Z, Barengo NC, Peltonen M, Tuomilehto $\mathrm{J}$ : The European perspective of type 2 diabetes prevention: diabetes in europe - Prevention Using Lifestyle, Physical Activity and Nutritional Intervention (DE-PLAN) Project. Exp Clin Endocrinol Diabetes 2008;116:167-72.

49 Hainer V, Toplak H , Mitrakou A: Treatment modalities of obesity: What fits whom? Diabetes Care 2008;31(suppl 2):S269-S277.

50 Sampsel S, May J: Assessment and management of obesity and comorbid conditions. Dis Manag 2007; 1:252-65.

51 Poirier P, Giles TD, Bray GA, Hong Y, Stern JS, PiSunyer FX, Eckel RH; American Heart Association; Obesity Committee of the Council on Nutrition, Physical Activity, and Metabolism: Obesity and cardiovascular disease: pathophysiology, evaluation, and effect of weight loss: an update of the 1997 American Heart Association Scientific Statement on Obesity and Heart Disease from the Obesity Committee of the Council on Nutrition, Physical Activity, and Metabolism. Circulation. 2006;113: 898-918.

52 WHO: Obesity: preventing and managing the global epidemic. Report of a WHO Consultation on Obesity, Geneva, 3-5 June 1997. WHO/NUT/NCD/ 98.1,1-276. 1998. Ref Type: Report.

53 Avenell A, Brown TJ, McGee MA, et al: What are the long-term benefits of weight reducing diets in adults? A systematic review of randomized controlled trials. J Hum Nutr Diet 2004;17:317-335.

54 Lahti-Koski M, Männistö S, Pietinen P, Vartiainen E: Prevalence of weight cycling and its relation to health indicators in Finland. Obes Res 2005;13: 333-341.

55 Marchesini G, Cuzzolaro M, Mannucci E, Dalle Grave R, Gennaro M, Tomasi F, Barantani EG, Melchionda N; QUOVADIS Study Group: Weight cycling in treatment-seeking obese persons: data from the QUOVADIS study. Int J Obes Relat Metab Disord 2004;28:1456-1462.
56 Anderson JW, Konz EC, Frederich RC, et al: Longterm weight-loss maintenance: a meta-analysis of US studies. Am J Clin Nutr 2001;74:579-584.

57 Dansinger ML, Tatsioni A, Wong JB, Chung M, Balk EM: Meta-analysis: the effect of dietary counseling for weight loss. Ann Intern Med 2007;147: 41-50.

58 Astrup A, Grunwald GK, Melanson EL, et al: The role of low-fat diets in body weight control: a metaanalysis of ad libitum dietary intervention studies. Int J Obes Relat Metab Disord 2000;24:1545-52.

59 Pirozzo S, Summerbell C, Cameron C, Glasziou P: Advice on low-fat diets for obesity. Cochrane Database Syst Rev 2002;(2):CD003640.

60 Nordmann AJ, Nordmann A, Briel M, et al: Effects of low-carbohydrate vs low-fat diets on weight loss and cardiovascular risk factors: a meta-analysis of randomized controlled trials. Arch Intern Med 2006;166:285-93.

61 Thomas DE, Elliott EJ, Baur L: Low glycaemic index or low glycaemic load diets for overweight and obesity. Cochrane Database Syst Rev 2007;(3) CD005105.

62 McMillan-Price J, Petocz P, Atkinson F, et al: Comparison of 4 diets of varying glycemic load on weight loss and cardiovascular risk reduction in overweight and obese young adults: a randomized controlled trial. Arch Intern Med 2006;166:1466-75.

63 Livesey G, Taylor R, Hulshof $\mathrm{T}$, Howlett J: Glycemic response and health - a systematic review and meta-analysis: relations between dietary glycemic properties and health outcomes. Am J Clin Nutr 2008;87:258S-268S.

64 Ayyad C, Andersen T: Long-term efficacy of dietary treatment of obesity: a systematic review of studies published between 1931 and 1999. Obes Rev 2000;1:113-9.

65 Heymsfield SB, van Mierlo CA, van der Knaap HC et al: Weight management using a meal replacement strategy: meta and pooling analysis from six studies. Int J Obes Relat Metab Disord 2003;27: 537-49.

66 Greenwald A: Current nutritional treatments of obesity. Adv Psychosom Med 2006;27:24-41

67 Sharma M: Behavioural interventions for preventing and treating obesity in adults. Obes Rev 2007;8 441-9.

68 Kay SJ, Fiatarone Singh MA: The influence of physical activity on abdominal fat: a systematic review of the literature. Obes Rev 2006;7:183-200.

69 Lee S, Kuk JL, Davidson LE, Hudson R, Kilpatrick K, Graham TE, Ross R: Exercise without weight loss is an effective strategy for obesity reduction in obese individuals with and without type 2 diabetes. J Appl Physiol 2005;99:1220-5.

70 Ross R, Janssen I, Dawson J, Kungl AM, Kuk JL, Wong SL, Nguyen-Duy TB, Lee S,Kilpatrick K, Hudson R: Exercise-induced reduction in obesity and insulin resistance in women: a randomized controlled trial. Obes Res 2004;12:789-98.

71 Jakicic JM, Otto AD: Physical activity considerations for the treatment and prevention of obesity. Am J Clin Nutr 2005;82(suppl 1):226S-229S.

72 Jakicic JM: Exercise in the treatment of obesity. Endocrinol Metab Clin North Am 2003;32:967-80.

73 Jakicic JM, Marcus BH, Gallagher KI, Napolitano M, Lang W: Effect of exercise duration and intensity on weight loss in overweight, sedentary women: a randomized trial. JAMA 2003;290:1323-30.

74 Stallmann-Jorgensen IS, Gutin B, Hatfield-Laube JL, Humphries MC, Johnson MH, Barbeau P: General and visceral adiposity in black and white adolescents and their relation with reported physical activity and diet. Int J Obes 2007;31:622-9. 
75 Saris WH, Blair SN, van Baak MA, Eaton SB, Davies PS, Di Pietro L, Fogelholm M,Rissanen A, Schoeller D, Swinburn B, Tremblay A, Westerterp KR, Wyatt H: How much physical activity is enough to prevent unhealthy weight gain? Outcome of the IASO 1st Stock Conference and consensus statement. Obes Rev 2003;4:101-14.

76 Padwal RS, Majumdar SR: Drug treatments for obesity: orlistat, sibutramine, and rimonabant. Lancet 2007;369:71-7.

77 Norris SL, Zhang X, Avenell A, Gregg E, Schmid $\mathrm{CH}$, Lau J: Pharmacotherapy for weight loss in adults with type 2 diabetes mellitus. Cochrane Database Syst Rev 2005;(2):CD004095.

78 Torgerson JS, Hauptman J, Boldrin MN, Sjöström $\mathrm{L}$ : Xenical in the prevention of diabetes in obese subjects (XENDOS) study: a randomized study of orlistat as an adjunct to lifestyle changes for theprevention of type 2 diabetes in obese patients. Diabetes Care 2004;27:155-61.

79 Christensen R, Kristensen PK, Bartels EM, Bliddal $\mathrm{H}$, Astrup A: Efficacy and safety of the weight-loss drug rimonabant: a meta-analysis of randomised trials. Lancet 2007;370:1706-13.

80 James WP, Astrup A, Finer N, Hilsted J, Kopelman P, Rössner S, Saris WH, Van Gaal LF: Effect of sibutramine on weight maintenance after weight loss: a randomized trial. STORM Study Group. Sibutramine Trial of Obesity Reduction and Maintenance. Lancet 2000;356:2119-25.
81 Curioni C, André C: Rimonabant for overweight or obesity. Cochrane Database Syst Rev 2006;(4):CD 006162.

82 O'Meara S, et al: A systematic review of the clinical effectiveness and cost effectiveness of orlistat in the management of obesity. Report commissioned by the NHS R and D HTA Programme on behalf of The National Institute for Clinical Excellence (NICE). 2000. www.nice.org.uk/pdf/orlistathta.pdf.

83 O'Meara S, et al: A systematic review of the clinical effectiveness and cost effectiveness of sibutramine in the management of obesity. Report commissioned by the NHS R and D HTA Programme on behalf of The National Institute for Clinical Excellence (NICE). 2000. www.nice.org.uk/pdf/sibutraminehtareport.pdf.

84 Kyrou I, Valsamakis G, Tsigos C: The endocannabinoid system as a target for the treatment of visceral obesity and metabolic syndrome. Ann N Y Acad Sci. 2006;1083:270-305.

85 Ridley N: Expert panel on weight loss surgery-executive report. Obes Surg 2005;13:206-26.

86 Levy P, Fried M, Santini F, Finer N: The comparative effects of bariatric surgery on weight and type 2 diabetes. Obes Surg 2007;9:1248-56.

87 Maggard MA, Shugarman LR, Suttorp M, Maglione M, Sugerman HJ, Livingston EH, Nguyen NT, Li Z, Mojica WA, Hilton L, Rhodes S, Morton SC, Shekelle PG: Meta-analysis: surgical treatment of obesity. Ann Intern Med 2005;142:547-59.
88 Sjöström L, Narbro K, Sjöström CD, Karason K, Larsson B, Wedel H, Lystig T, Sullivan M, Bouchard C, Carlsson B, Bengtsson C, Dahlgren S, Gummesson A, Jacobson P, Karlsson J, Lindroos AK, Lönroth H, Näslund I, Olbers T, Stenlöf K, Torgerson J, Agren G, Carlsson LM; Swedish Obese Subjects Study: Effects of bariatric surgery on mortality in Swedish obese subjects. N Engl J Med 2007;357: 741-52.

89 Sjöström L, Lindroos AK, Peltonen M, Torgerson J, Bouchard C, Carlsson B,Dahlgren S, Larsson B, Narbro K, Sjöström CD, Sullivan M, Wedel H; Swedish Obese Subjects Study Scientific Group: Lifestyle, diabetes, and cardiovascular risk factors 10 years after bariatric surgery. N Engl J Med 2004; 351:2683-93.

90 Adams TD, Gress RE, Smith SC, Halverson RC, Simper SC, Rosamond WD, Lamonte MJ, Stroup AM, Hunt SC: Long-term mortality after gastric bypass surgery. N Engl J Med 2007;357:753-61.

91 van Dielen FM, Soeters PB, de Brauw LM, Greve JW: Laparoscopic adjustable gastric banding versus open vertical banded gastroplasty: a prospective randomized trial. Obes Surg 2005;15:1292-8. 